\title{
A Rainy Month Performance Evaluation of Photovoltaic Module and Performance Prediction of the PV Water Pumping Systems Under Soudano Sahelian Climate
}

\author{
Kodji Deli $^{1, *}$, Noel Djongyang ${ }^{1}$, Donatien Njomo $^{2}$, Dieudonné Kidmo ${ }^{1}$ \\ ${ }^{1}$ Department of Renewable Energy, National Advanced Polytechnic School, University of Maroua, Maroua, Cameroon \\ ${ }^{2}$ Department of Physics, Faculty of Science, University of Yaoundé I, Yaoundé, Cameroon
}

Email address:

delikodji27@yahoo.fr (K. Deli), noeldjongyang@gmail.com (N. Djongyang), dnjomo@usa.net (D. Njomo),

kidmokaoga $@$ gmail.com (D. Kidmo)

${ }^{*}$ Corresponding author

\section{To cite this article:}

Kodji Deli, Noel Djongyang, Donatien Njomo, Dieudonné Kidmo. A Rainy Month Performance Evaluation of Photovoltaic Module and Performance Prediction of the PV Water Pumping Systems Under Soudano Sahelian Climate Conditions. International Journal of Electrical Components and Energy Conversion. Vol. 4, No. 1, 2018, pp. 61-71. doi: 10.11648/j.ijecec.20180401.17

Received: May 21, 2018; Accepted: June 6, 2018; Published: August 1, 2018

\begin{abstract}
The purpose of this paper is to evaluate the energy yield of the photovoltaic module during the worst case conditions in Soudano Sahelian climate in order to predict real time worst performance of a PV water pumping systems in two stations in soudano-sahelian zone of Cameroon. a simple model has been developed with experimental data of electrical energy delivered by PV module for estimating the performance of a photovoltaic (PV) water pumping systems, this work is made possible using 5-min intervals of measured performance data (ambient temperature, current, voltage) for the month of August using the optimum fixed tilt angle of the PV array. The method is validated by predicting the performance of two PV pumping systems installed in an isolated site in Agola and Dorigué. The daily and the monthly flow rate of the systems predicted by the method are evaluated.
\end{abstract}

Keywords: PV Water Pumping Systems, Performance, Worst Month, Soudano Sahelian Climate Conditions

\section{Introduction}

Photovoltaic (PV) power generation system is one of the most popular uses of the direct solar energy and its installation is rapidly growing because it is considered as a clean and environmentally friendly source of energy. A PV power generation system contains a number of PV modules that converts solar radiation into direct electrical current using semiconducting materials [1]. PV cell can be utilized to power different systems, for example, PV water pumping systems. However, the high cost of solar cells is an obstacle to expansion of their use. This is because during the operation of the PV cell, only around $15 \%$ of solar radiation is converted to electricity with the rest converted into heat. The electrical efficiency will decrease when the operating temperature of the PV module increases [2]. Solar irradiance has the greatest impact on the power output of a PV system [3]. Beyond irradiance, weather conditions such as ambient temperature along with several other factors: angle of incidence, dust, may also affect a module's or an array's power output and energy production. [4].

To model the annual performance of photovoltaic modules their performance characteristics are needed [5, 6]. The available information from manufacturers are typically limited to temperature coefficients, short circuit current Isc, open circuit voltage $V$ oc, and the maximum power $P_{\text {max }}$, at rating conditions $\left(\mathrm{G}=1000 \mathrm{~W} / \mathrm{m}^{2}, \mathrm{~T}_{\mathrm{c}}=25^{\circ} \mathrm{C}, \mathrm{AM}=1,5\right)$. These informations are useful when one want to compare photovoltaic module performance at rating conditions but are inadequate to predict annual performance under typical operating conditions $[7,8]$. It is demonstrated that there is difference between expected power production forecasts and field experience of photovoltaic arrays [9]. It has been shown that the relative performance ranking at rating conditions may not agree with the ranking based on monthly or annual performance. Discrepancies between the rated and annual 
rankings are attributed to the large annual variations that are experienced in incident angle, solar spectrum, operating temperature, and solar irradiance as compared to the typical rating conditions [7]. Real performance analysis is fundamental to develop models and simulation tools used to predict energy production of PV. Various studies have been developed with the final aim of assessing and comparing the performance of different types of PV modules and technologies in specific geographical locations and under various climatic conditions. [10-13] These studies can help to take economical decisions $[14,15]$.

Optimum standalone PV system sizing process is mainly depending on meteorological data such as solar radiation and ambient temperature. Meteorological variables in standalone PV system sizing process are important since the output energy of these systems strongly depends on the availability of these data $[16,17]$. These data can help designers to improve system's efficiency and reliably so as to meet the end user requirements at a desired level of availability and acceptable range of cost [18]. Most of sizing methodologies use mean monthly data of solar irradiation over the years and the worst month data is used in order to satisfy energy requirements all over the year [19].

Once power output of the solar module is known it can be used to model and predict water pumping particularly in developing countries where there is a great need on water for domestic, agricultural and industrial applications. Many research efforts have focused on the development of empirical models that are able to predict PV water pumping system performance for any climatic condition using various parameters. These parameters include global solar radiation, ambient temperature, temperature of a PV module, latitude, longitude, albedo, orientation and inclination of PV array, nominal PV module efficiency, NOCT, PV array area, PV temperature coefficient, miscellaneous power conditioning losses, miscellaneous PV array losses, temperature of reference, and moto-pump and inverter efficiency [20, 2, 21].

The objective of this paper is to study the performance of the specific commercial PV module into specific climatic conditions and to use measured power output to predict performance of water pumping stations by evaluating the water flow rate during worst month conditions of two water pumping stations in the northern Cameroon.

\subsection{Description of the PV Module Used for Experimental Procedure}

One type of photovoltaic modules is used in the experimental procedure. The module is made by GS new energy types GS 075 , rated $75 \mathrm{Wp}$ other characteristics are given in the table 1 .
Table 1. Characteristics of PV Solar module.

\begin{tabular}{ll}
\hline Model type & GS 075 \\
\hline Rated max power $\left(P_{\max }\right)$ & $75 \mathrm{~W}$ \\
Current at Pmax $\left.\left(I_{\operatorname{mp}}\right)\right)$ & $4.36 \mathrm{~A}$ \\
Voltage at Pmax $\left(V_{\operatorname{mp}}\right)$ & $17.2 \mathrm{~V}$ \\
Short circuit current $\left(I_{S C}\right)$ & $4.60 \mathrm{~A}$ \\
Open circuit voltage $\left(V_{O C}\right)$ & $21.6 \mathrm{~V}$ \\
Nominal operating cell temperature $\left(T_{N O C T}\right)$ & $48+/-2{ }^{\circ} \mathrm{C}$ \\
weight & $8 \mathrm{Kg}$ \\
Max system voltage & $1000 \mathrm{~V}$ \\
Max series fuse rating & $8 \mathrm{~A}$ \\
Module efficiency & $11.7 \%$ \\
Temperature Range & $-40-85{ }^{\circ} \mathrm{C}$ \\
Temperature coefficient $\left(P_{\max }\right)$ & $-0.5 \% /{ }^{\circ} \mathrm{C}$ \\
Temperature Coefficient $\left(V_{O C}\right)$ & $-0.37 \% /{ }^{\circ} \mathrm{C}$ \\
Temperature coefficient $\left.\left(I_{S C}\right)\right)$ & $0.035 \% /{ }^{\circ} \mathrm{C}$ \\
Module dimensions & $1196 \times 534 \times 35 \mathrm{~mm}$ \\
\hline
\end{tabular}

\subsection{Description of the PV Water Pumping Systems}

Two solar water pumping stations are selected as the case study for the determination of the pumping performances. The first station named Agola $\left(10^{\circ} 19^{\prime} \mathrm{N}\right.$ and $15^{\circ} 16^{\prime} \mathrm{E}, 319 \mathrm{~m}$ altitude) and the second station named Dorigué ( $9^{\circ} 59^{\prime} \mathrm{N}$ and $15^{\circ} 25^{\prime} \mathrm{E}, 325 \mathrm{~m}$ altitude). Both stations are located at isolated sites with a Soudano-sahelian climate near the city of Yagoua in far North Cameroon.

The two systems are used to provide potable water for population and cattle. The first and second stations consists of 8 monocrystalline panels $(75 \mathrm{~W}, 12 \mathrm{~V}, 4$ in series and 2 parallel). A submersible pump is type from Grundfos SQFlex 2,5-2. It is protected against dry running which is activated by the included water level electrode placed on the motor cable $0.3-0.6 \mathrm{~m}$ above the pump, it has a built-in with Maximum Power Point Tracking (MPPT) available only for pumps connected to solar panels function. The pump duty point is continuously optimised according to the input power available. The performance curves of SQFlex 2,5-2 is presented in Figure 1. The pump is driven motors with MSF3N with a maximum power input of $1400 \mathrm{~W}$ and maximum current of $8.4 \mathrm{~A}$.

The piping system delivers potable water from the deep well to a 6 and $4 \mathrm{~m}^{3}$ capacity storage tank respectively. The modules in the two stations are mounted on a supporting structure so that the surface azimuth angle and the inclination angle of the modules are zero and $15^{\circ}$, respectively. A PV water pumping system consists of a PV array, inverter, submersible pump, storage tank, and auxiliary system of measuring devices and weather monitoring sensors, the two stations work without storage batteries. The photographs and characteristics of the PV pumping stations are shown in Figure 2 and Table 2, respectively. 


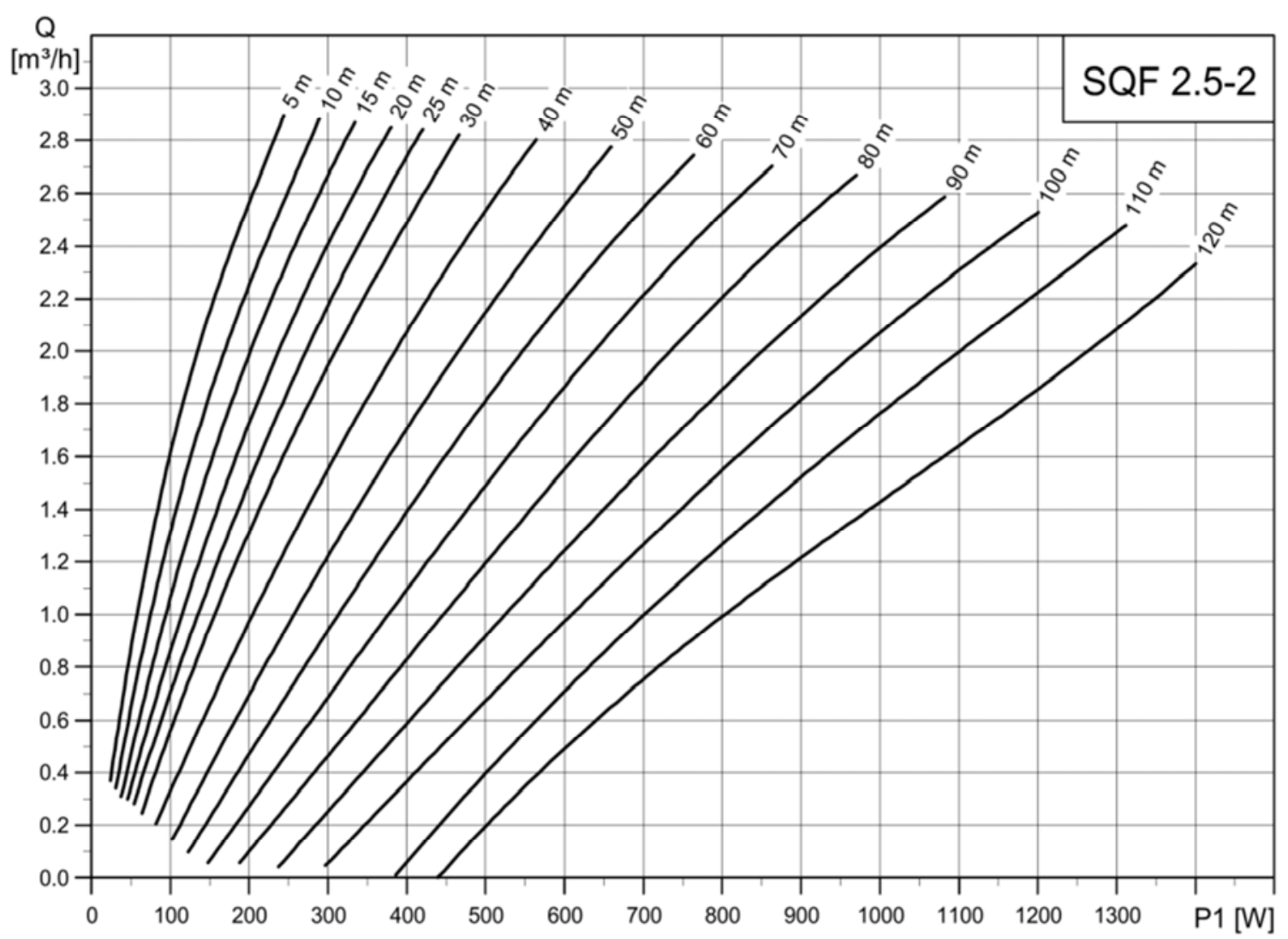

Figure 1. Performance curves of SQflex 2.5-2 [22].

Table 2. Characteristics of the PV Pumping Stations.

\begin{tabular}{lll}
\hline Station & Station of Agola & Station of Dorigué \\
\hline Power installed $(\mathrm{Wp})$ & 600 & 600 \\
Total head $(\mathrm{m})$ & 60 & 80 \\
Storage capacity $\left(\mathrm{m}^{3}\right)$ & 6 & 4 \\
Inclination angle of the module $\left({ }^{\circ}\right)$ & 15 & 15 \\
Number of module & 8 & 8 \\
Nominal PV module efficiency & $11.7 \%$ & $11.7 \%$ \\
$\mathrm{PV}$ temperature coefficient $\left(\% /{ }^{\circ} \mathrm{C}\right)$ & 0.4 & 0.4 \\
PV array area $\left(\mathrm{m}^{2}\right)$ & 5.109312 & 5.109312 \\
Reference temperature $\left({ }^{\circ} \mathrm{C}\right)$ & 25 & 25 \\
Pump type & SQFlex $2.5-2$ & SQFlex $2.5-2$ \\
Pump range voltage & $30-300$ VDC or $90-240$ VAC & $30-300$ VDC or $90-240$ VAC \\
Pump manufacturer & Grunfos & Grunfos \\
Pump system efficiency & 45 & 45 \\
\hline
\end{tabular}

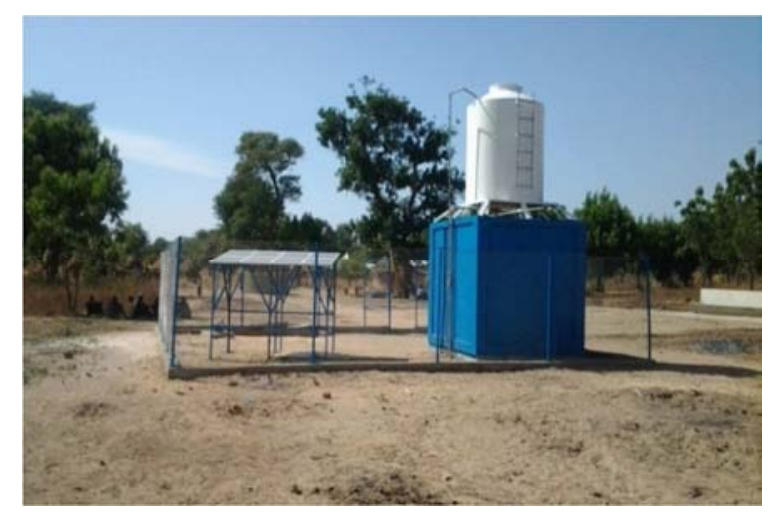

(a)

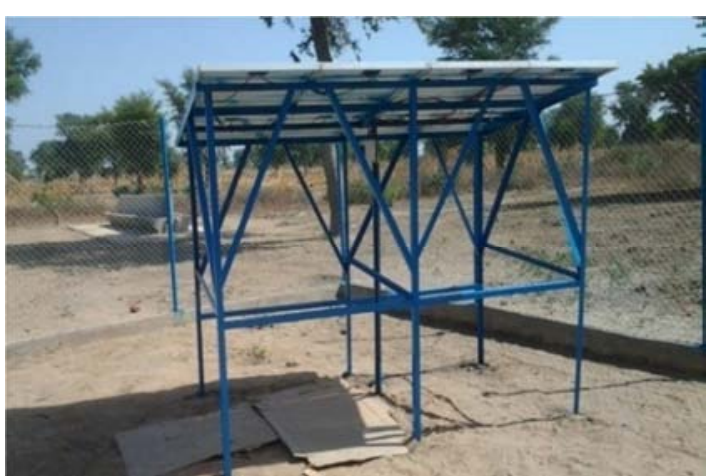

(b)

Figure 2. Photograph of the station of Agola (a) and PV generator of the system (b). 
Water pump can be powered by 30-300 VDC or 90-240 VAC $-10 \% /+6 \%, 50 / 60 \mathrm{~Hz}$, the run up time depends on energy source and there is no limitation of the number of starts/stop per hour. The pump must be completely submerged in the pumped liquid and must be placed at maximum $150 \mathrm{~m}$ below the static water level (15 bars). It is equipped with two elements: a CU 200 SQFlex control unit with $5 \mathrm{~W}$ power consumption, $10 \mathrm{~A}$ maximum back-up fuse and the IO 100 SQFlex switch box with 300VDC, 265VAC maximum voltage and $8,5 \mathrm{~A}$ current. Their operating temperature is in the range of $-30 / 50^{\circ} \mathrm{C}$.

\section{Experimental Setup and Methodology}

The system performance is evaluated by measuring the parameters of a photovoltaic module (GS075) with characteristics described in Table 1 the parameters measured are ambient temperature, maximum current and voltage with sensors of Very high sensitivity these sensors are associated to the ALMEMO 2690-8, which have five inputs measured inputs M0 to M4 for all ALMEMO Sensors and 15 additional channels M10... M34. The experimental protocol is presented in the Figure 3.

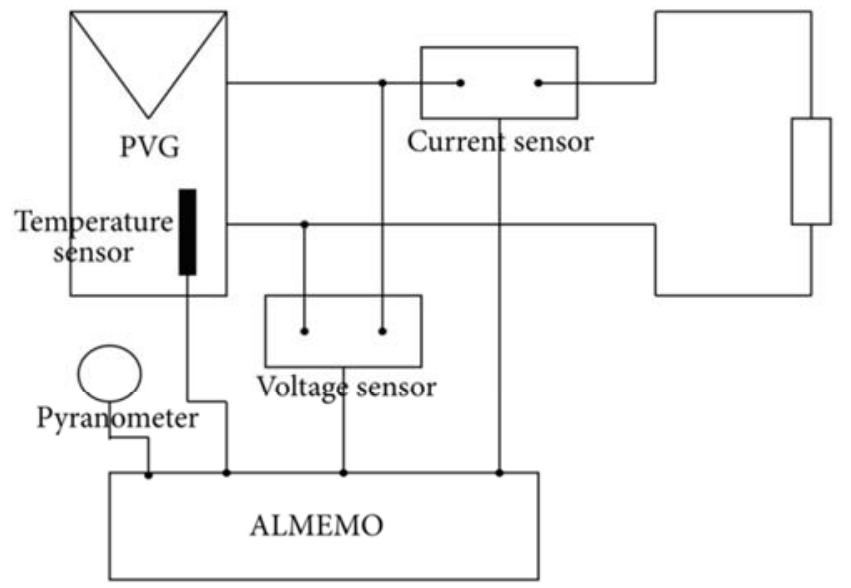

Figure 3. Experimental protocol schematic.

\subsection{Electrical Output of the PV Array}

The maximum power of the PV module is given by the following formula

$$
P_{m}=I_{m} V_{m}=(F F) I_{s c} V_{o c}
$$

The efficiency of the PV module on site is given by the following formula

$$
\eta_{p}=\eta_{r e f}\left[1-\beta_{r e f}\left(T_{c}-T_{r e f}\right)+\gamma \log _{10} I(t)\right]
$$

In which $\eta_{r e f}$ is the module's electrical efficiency at the reference temperature, $T_{\text {ref }}$ and at solar radiation of $1000 \mathrm{~W} / \mathrm{m}^{2}$. The temperature coefficient, $\beta_{\text {ref }}$, and the solar radiation coefficient, $\gamma$, are mainly material properties, having values of about $0.004 \mathrm{~K}^{-1}$ and 0.12 , respectively, for crystalline silicon modules [23]. $\gamma$, however, is usually taken as zero [24] and equation is reduces to:

$$
\eta_{p}=\eta_{r e f}\left[1-\beta_{r e f}\left(T_{c}-T_{r e f}\right)\right]
$$

This represents the traditional linear expression for the PV electrical efficiency [25]. The quantities $\eta_{r e f}$ and $\beta_{\text {ref }}$ are normally given by the PV manufacturer. However, they can be obtained from flash tests in which the module's electrical output is measured at two different temperatures for a given solar radiation flux [26]. The actual value of the temperature coefficient, in particular, depends not only on the PV material but on $T_{r e f}$ as well. It is given by the ratio

$$
\beta_{\text {ref }}=\frac{1}{T_{0}-T_{\text {ref }}}
$$

In which $T_{0}$ is the (high) temperature at which the PV module's electrical efficiency drops to zero [27]. For crystalline silicon solar cells this temperature is $270^{\circ} \mathrm{C}$ [28].

The energy delivered by the PV array $E_{e}$, is given by Evans [24].

$$
E_{e}=A \eta_{p} H_{t}\left(1-\lambda_{p}\right)\left(1-\lambda_{c}\right)
$$

Where $A$ is the area of the array. It has to be reduced by miscellaneous PV array losses $\lambda_{p}$ and other power conditioning losses $\lambda_{c}$.

\subsection{Water Pumping Model}

The water pumping model is based on the simple equations [29]. The hourly hydraulic energy demand $E_{h y d r}$ (Wh), corresponding to lifting water to a height $h(\mathrm{~m})$ with a hourly volume $Q(\mathrm{~m} 3 / \mathrm{h})$ is:

$$
E_{\text {hydr }}=\rho g Q h\left(1+\eta_{f}\right)=\rho g Q H M T
$$

Where $g$ is the acceleration of gravity $\left(9.81 \mathrm{~m} / \mathrm{s}^{2}\right), \rho$ is the density of water $\left(1000 \mathrm{~kg} / \mathrm{m}^{3}\right)$ and $\eta_{f}$ is a factor accounting for friction losses in the piping in percentage of geometric head $h$. This hydraulic energy translates into an electrical energy requirement $E_{e}$ :

$$
E_{e}=\left(\frac{E_{h y d r}}{R_{p}}\right)
$$

Where $R_{\mathrm{p}}$ is the pump system efficiency. If the pump is $\mathrm{AC}$, this equation has to be modified to take into account the inverter efficiency $R_{\text {inv }}$ :

$$
\begin{gathered}
E_{e}=\left(\frac{E_{h y d r}}{R_{p} R_{i n v}}\right) \\
E_{e}=\left(\frac{\rho g Q H M T}{R_{p} R_{\text {inv }}}\right)=A \eta_{p} H_{t}\left(1-\lambda_{p}\right)\left(1-\lambda_{c}\right)
\end{gathered}
$$

The hourly volume pumping (flow rate) $Q\left(\mathrm{~m}^{3} / \mathrm{h}\right)$, which can be expressed as:

$$
Q=\left(\frac{A \eta_{p} H_{t}\left(1-\lambda_{p}\right)\left(1-\lambda_{c}\right) R_{p} R_{i n v}}{\rho g H M T}\right)
$$

\subsection{Head Losses in the Pipe}

The Head losses $H_{f}$ (in meters of liquid) are produced by friction of the fluid on the walls of the pipes; by changes of 
section or direction. Today, there are two principle formulas for determining pipe friction. These are the Darcy-Weisbach and the Colebrook formulas [30-32]. Thus the Friction losses in a cylindrical pipe of diameter $\mathrm{D}$ and of length $\mathrm{L}$ is given by:

$$
H_{f}=\left(f \frac{L}{D}\right) \frac{U^{2}}{2 g}
$$

$f$ is the friction factor it is dimensionless and is only a function of the Reynolds number $R_{e}=\frac{U D}{v}$ and the roughness of the wall.

For $R_{e}<2000$, the flow is laminar and $f=\frac{64}{R_{e}}$

For $R_{e}>2000$, the flow is generally turbulent. If one can characterize the roughness of the walls by a single linear parameter $\varepsilon$ then $f$ is given by the Colebrook formula [31, 32].

$$
\frac{1}{\sqrt{f}}=-2 \log \left(\frac{\varepsilon}{3,7 D}+\frac{2,51}{R_{e} \sqrt{f}}\right)
$$

However, this formula requires the use of relatively complex successive approximation methods. If the roughness is low, the pipe behaves as hydraulically smooth and we have:

$$
\frac{1}{\sqrt{f}}=2 \log \frac{R_{e} \sqrt{f}}{2,51}
$$

This expression for $R_{e}<10^{5}$ can be replaced by a simpler Blasius formula [31].

$$
f=\frac{0,316}{R_{e}{ }^{1 / 4}}
$$

If the roughness is strong, the behavior behaves as hydraulically rough and we have, for a higher value of $R_{e}$

$$
\frac{1}{\sqrt{f}}=2 \log \left(3,71 \frac{D}{\varepsilon}\right)=1,74+2 \log \frac{D}{2 \varepsilon}
$$

In practice, diagrams or charts are used to calculate the values of $f$, as a function of $R_{e}$ and $\frac{\varepsilon}{D}$ as shown in the Figure 4. The roughness of different materials used as piping is presented in Table 3.

Table 3. Roughness of different materials used as piping [33].

\begin{tabular}{ll}
\hline Materials & Roughness (mm) \\
\hline PVC & $0.01-0.05$ \\
Pipe in aluminium, copper og brass & $0-0.003$ \\
Steel pipe & $0.01-0.05$ \\
Welded steel pipe, new & $0.03-0.15$ \\
Welded steel pipe with deposition & $0.15-0.30$ \\
Galvanized steel pipe, new & $0.1-0.2$ \\
Galvanized steel pipe with deposition & $0.5-1.0$ \\
\hline
\end{tabular}

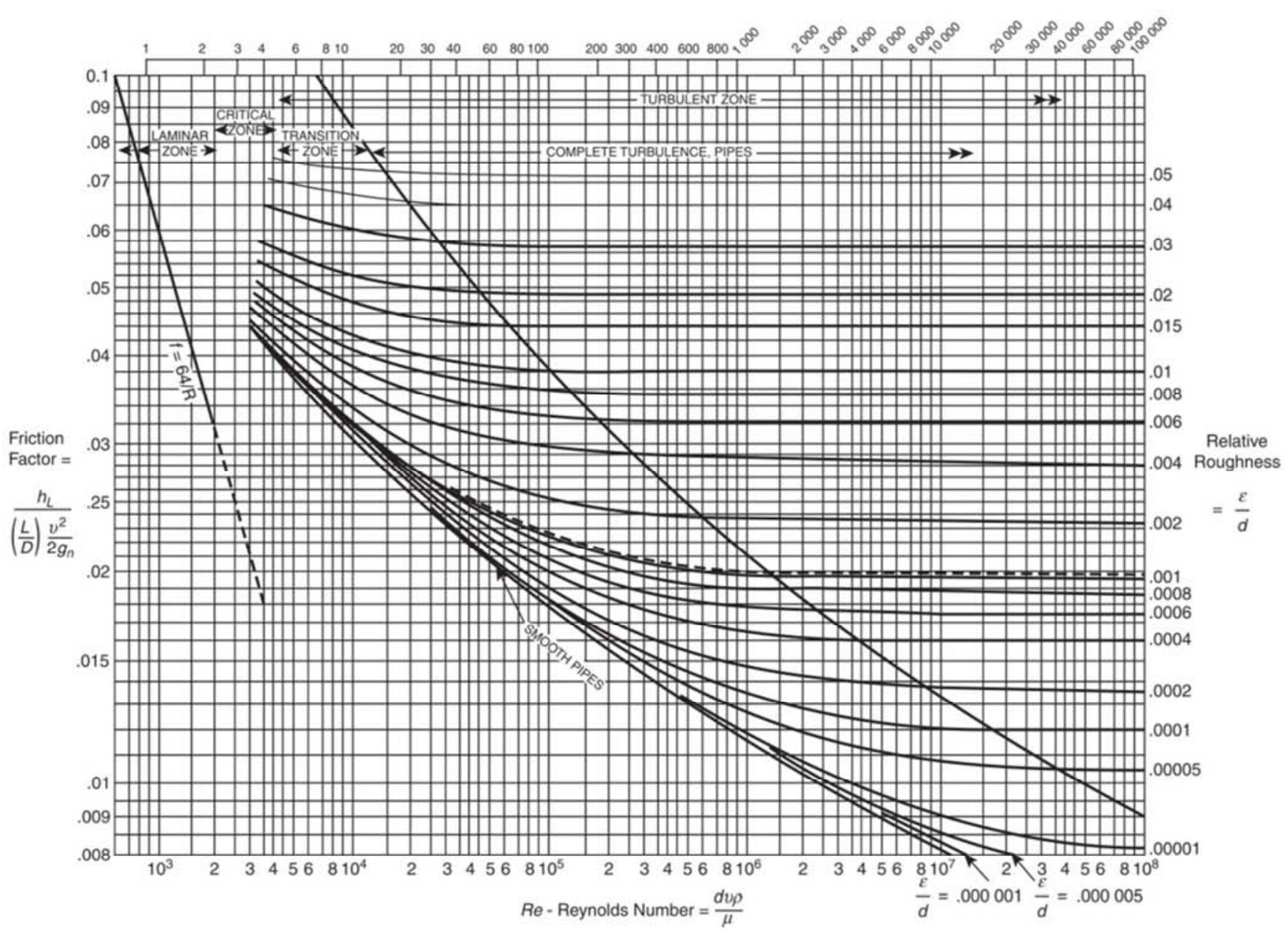

Figure 4. Moody's diagram used to determine the friction factor [30, 31]. 


\section{Results and Discussion}

\subsection{PV Module Performance}

During the period of investigation the on field measurement of different parameters (Temperature, current, voltage) permitted to calculate the PV module power and energy production from PV arrays. It also permitted to evaluate the filling factor (FF) of the PV module. It appears that for the whole month of August, the sunny day corresponded to $09^{\text {th }}$ of August and the worst day correspond to $04^{\text {th }}$ of August. For the sunny day the maximum power and FF reached are respectively $87.64 \mathrm{~W}$ and 0.85 . For the same day the energy produced was $420.1 \mathrm{Wh}$ while mean power and FF were respectively $43.84 \mathrm{~W}$ and 0.42 . For the worst day ( $04^{\text {th }}$ of August) the maximum power and $\mathrm{FF}$ reached were $56.48 \mathrm{~W}$ and 0.54 . The mean power and FF were respectively 25.48 and 0.246 . Other details are presented in Table 4:

Table 4. On field data measured of the GS075 PV module.

\begin{tabular}{|c|c|c|c|c|c|c|c|c|c|c|c|}
\hline \multicolumn{12}{|c|}{ Measured performance parameters of PV module (GS075) during the month of August 2016} \\
\hline Days & $\begin{array}{l}\text { Maximum } \\
\text { Power }(W)\end{array}$ & $\begin{array}{l}\text { Mean } \\
\text { Power (W) }\end{array}$ & $\begin{array}{l}\text { Energy } \\
\text { (wh) }\end{array}$ & $\begin{array}{l}\text { Mean } \\
\text { FF } \\
\end{array}$ & $\begin{array}{l}\text { Max } \\
\text { FF } \\
\end{array}$ & Days & $\begin{array}{l}\text { Maximum } \\
\text { Power }(W)\end{array}$ & $\begin{array}{l}\text { Mean } \\
\text { Power }(W)\end{array}$ & $\begin{array}{l}\text { Energy } \\
\text { (wh) }\end{array}$ & $\begin{array}{l}\text { Mean } \\
\text { FF } \\
\end{array}$ & $\begin{array}{l}\text { Max } \\
\text { FF } \\
\end{array}$ \\
\hline 1 & 60.55 & 37.99 & 373.55 & 0.366 & 0.58 & 16 & 57.35 & 25.99 & 287.12 & 0.237 & 0.59 \\
\hline 2 & 56.92 & 37.65 & 363.96 & 0.363 & 0.55 & 17 & 66.11 & 28.00 & 266.63 & 0.268 & 0.61 \\
\hline 3 & 63.61 & 38.18 & 365.91 & 0.368 & 0.63 & 18 & 67.00 & 27.35 & 250.56 & 0.245 & 0.58 \\
\hline 4 & 56.48 & 25.48 & 250.53 & 0.246 & 0.54 & 19 & 73.36 & 33.78 & 311.25 & 0.312 & 0.80 \\
\hline 5 & 68.94 & 31.60 & 300.16 & 0.305 & 0.66 & 20 & 55.44 & 24.55 & 278.51 & 0.225 & 0.58 \\
\hline 6 & 58.78 & 28.93 & 260.38 & 0.279 & 0.57 & 21 & 72.45 & 31.24 & 300.52 & 0.303 & 0.65 \\
\hline 7 & 60.68 & 28.60 & 279.68 & 0.275 & 0.58 & 22 & 56.10 & 27.88 & 253.26 & 0.254 & 0.59 \\
\hline 8 & 79.72 & 33.05 & 327.71 & 0.319 & 0.69 & 23 & 84.56 & 34.79 & 315.26 & 0.317 & 0.69 \\
\hline 9 & 87.64 & 43.84 & 420.11 & 0.423 & 0.85 & 24 & 56.45 & 24.43 & 376.46 & 0.375 & 0.65 \\
\hline 10 & 63.01 & 29.48 & 289.89 & 0.284 & 0.65 & 25 & 59.36 & 27.45 & 250.53 & 0.251 & 0.65 \\
\hline 11 & 87.23 & 40.55 & 391.37 & 0.393 & 0.81 & 26 & 72.45 & 32.79 & 300.16 & 0.299 & 0.80 \\
\hline 12 & 70.55 & 30.35 & 300.13 & 0.304 & 0.68 & 27 & 70.43 & 31.00 & 292.65 & 0.293 & 0.74 \\
\hline 14 & 53.57 & 24.79 & 236.46 & 0.238 & 0.51 & 29 & 69.35 & 31.79 & 291.84 & 0.292 & 0.68 \\
\hline \multirow[t]{2}{*}{15} & 67.65 & 28.45 & 275.56 & 0.277 & 0.61 & 30 & 55.45 & 28.22 & 255.36 & 0.256 & 0.60 \\
\hline & & & & & & 31 & 88.77 & 33.77 & 311.25 & 0.314 & 0.80 \\
\hline
\end{tabular}

For the two special days identified, all measured parameters (Ambient Temperature, Current, Voltage, power and energy) are plotted. Alongside solar irradiation, Another factor which is prejudicial to the good behavior the PV array is the ambient temperature. Observations from Figure 5 shows variability between temperature on sunny day (more constant in afternoon) and worst day (more constant in the morning). The temperature can reach $39.48^{\circ} \mathrm{C}$ on the sunny day and $40.10^{\circ} \mathrm{C}$ on the worst day.

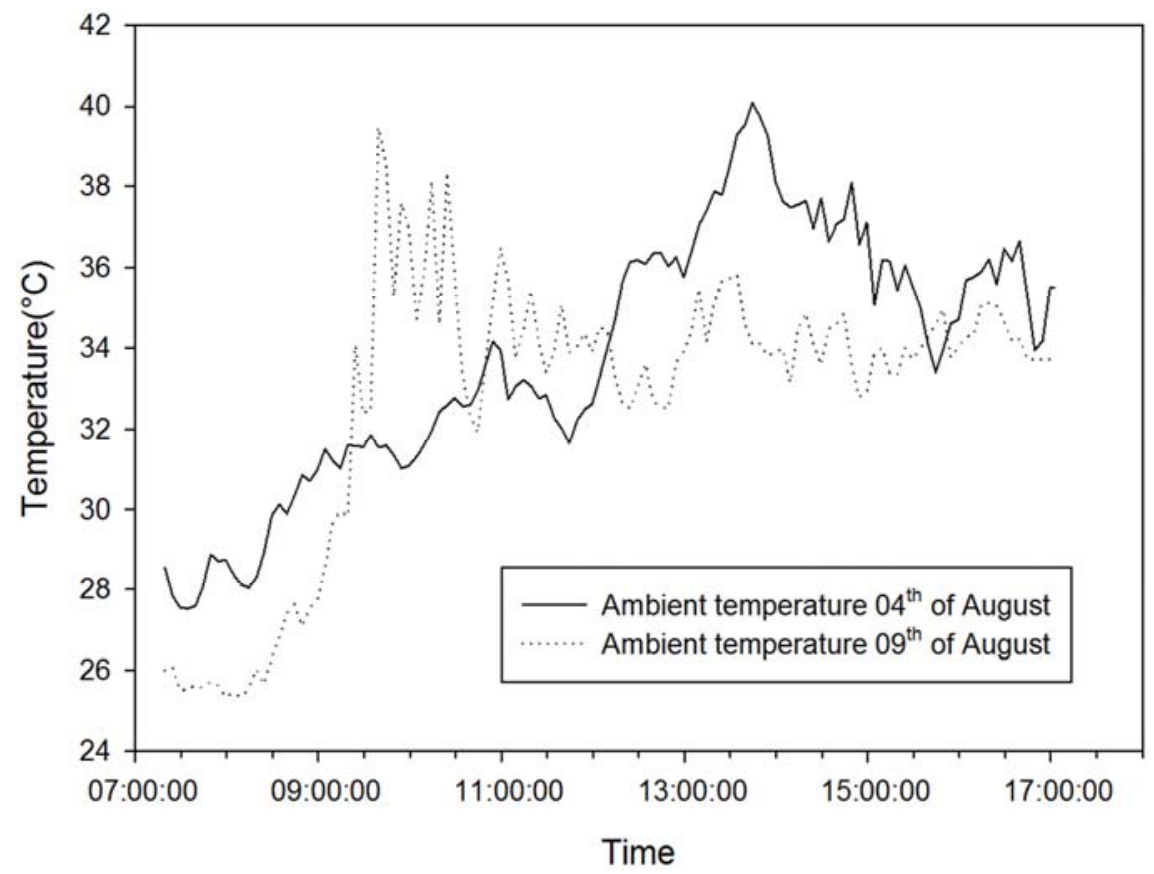

Figure 5. Ambient temperature measured during the worst and sunny day of August 2016. 
The most important parameters to take into account for the evaluation of the output power of the PV module are current and voltage. From the Figure 6 (worst day) it appears that voltage vary from 12.7 V (7:00 a.m.) to 16.9 V (1:59 p.m.) while current vary from $0.66 \mathrm{~A}(7 \mathrm{PM})$ to $3.44 \mathrm{~A}(1: 39$ p.m.) For the sunny day (Figure 7) voltage vary from $12.89 \mathrm{~V}(9: 08$ a.m.) to $15 \mathrm{~V}$ (11:16 a.m.) while current vary from $0.08 \mathrm{~A}(5$ p.m.) to $6.03 \mathrm{~A}(12: 51$ p.m.). However voltage remains more constant that current during the days of investigation, which is in perfect agreement with the theoretical results.

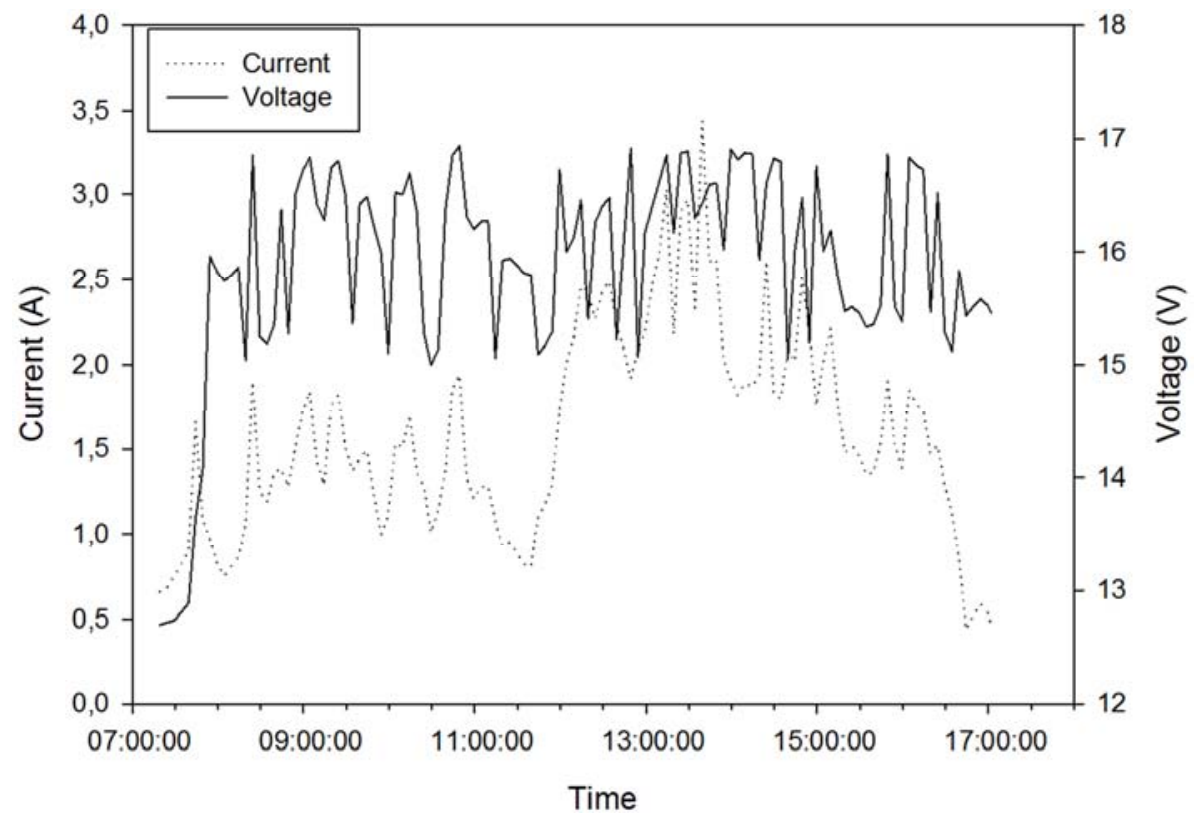

Figure 6. Current and voltage measures of the PV module 04th August 2016.

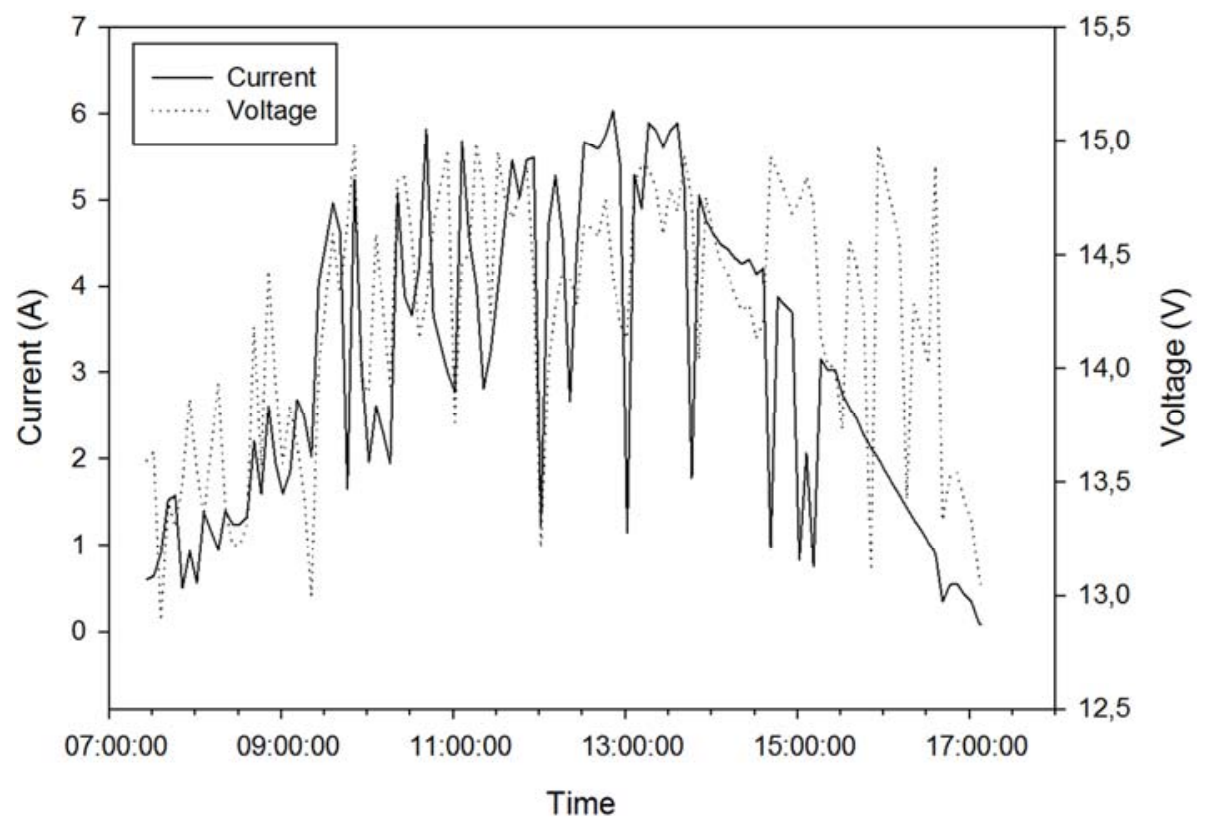

Figure 7. Current and voltage measures of the PV module 09th August 2016.

To evaluate the performance of PV systems the electrical power output is calculated from measured current and voltage data. Figure 8 present the evolution of the electrical power of the module during the worst and sunny day. Observations from this figure shows that for the sunny day, power vary from 0 to $87.64 \mathrm{~W}$ (which is $16.8 \%$ more than reference value of the power of the module at $1000 \mathrm{~W} / \mathrm{m}^{2}$, $25^{\circ} \mathrm{C}$ and $1.5 \mathrm{AM}$ ) while for the worst day it vary from 0 to $56.48 \mathrm{~W}$ (which is $24.7 \%$ less than reference value of power of the module). The mean value of power from 7.a.m to 5.p.m is respectively $25.47 \mathrm{~W}$ and $43.83 \mathrm{~W}$ for the worst day and sunny day. 


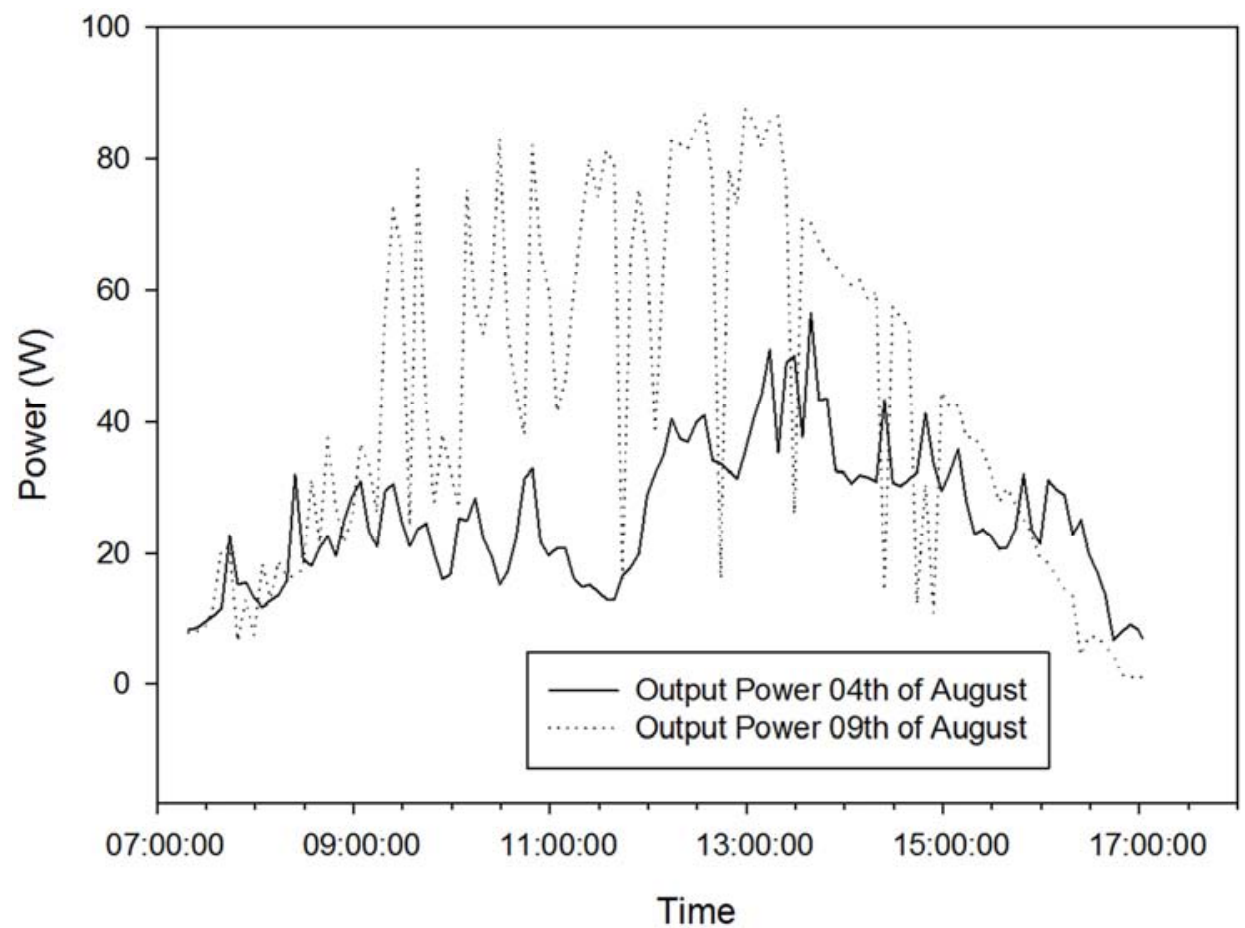

Figure 8. Electrical output power measured during the worst and sunny day of August.

\subsection{PV Water Pumping System Performance}

Two solar water pumping stations were selected as the case study namely Agola and Dorigué. These two stations have respectively the total head $(\mathrm{TH}) 60 \mathrm{~m}$ and $80 \mathrm{~m}$ their head loses have been evaluated using formula (11) to (15) and moody's diagram. Stations consist of 8 photovoltaic modules. Each module has the same characteristics with PV module studied above. Miscellaneous PV array losses (\%) and miscellaneous power conditioning losses (\%) have to be neglected since measures have been done directly and pumping stations are connected to the DC water pump. For these reasons the performance parameters of the two stations will be the same since they are located in the same climatic zone. Parameters are hence presented in the Table 5 the daily mean value of the power output of the stations during the month vary from $195.46 \mathrm{~W}$ to $350.70 \mathrm{~W}$ while daily maximum power vary from $428.54 \mathrm{~W}$ to $710.12 \mathrm{~W}$. The daily energy produced vary from $2004.27 \mathrm{Wh}$ to $3360.88 \mathrm{Wh}$.

Table 5. Performance parameters of two PV Water pumping stations.

\begin{tabular}{|c|c|c|c|c|c|c|c|}
\hline \multicolumn{8}{|c|}{ Measured performance parameters of PV pumping station month of August 2016} \\
\hline Days & Maximum Power (W) & Mean Power (W) & Energy (wh) & Days & Maximum Power (W) & Mean Power (W) & Energy (wh) \\
\hline 1 & 484.42 & 303.90 & 2988.38 & 16 & 458.76 & 207.89 & 2296.98 \\
\hline 3 & 508.87 & 305.46 & 2927.29 & 18 & 536.04 & 218.76 & 2004.51 \\
\hline 4 & 451.88 & 203.82 & 2004.27 & 19 & 586.85 & 270.21 & 2490.03 \\
\hline 5 & 551.55 & 252.77 & 2401.27 & 20 & 443.48 & 196.37 & 2228.12 \\
\hline 6 & 470.28 & 231.45 & 2083.06 & 21 & 579.63 & 249.89 & 2404.18 \\
\hline 7 & 485.40 & 228.81 & 2237.46 & 22 & 448.79 & 223.01 & 2026.05 \\
\hline 8 & 637.74 & 264.37 & 2621.71 & 23 & 676.52 & 278.31 & 2522.05 \\
\hline 9 & 701.15 & 350.70 & 3360.88 & 24 & 451.62 & 195.46 & 3011.65 \\
\hline 10 & 504.06 & 235.84 & 2319.10 & 25 & 474.85 & 219.58 & 2004.27 \\
\hline 11 & 697.88 & 324.37 & 3130.93 & 26 & 579.63 & 262.31 & 2401.27 \\
\hline 13 & 640.99 & 320.05 & 3121.00 & 28 & 670.29 & 325.26 & 3044.19 \\
\hline 14 & 428.54 & 198.31 & 1891.66 & 29 & 554.76 & 254.31 & 2334.68 \\
\hline \multirow[t]{2}{*}{15} & 541.23 & 227.63 & 2204.51 & 30 & 443.63 & 225.79 & 2042.86 \\
\hline & & & & 31 & 710.12 & 270.15 & 2490.04 \\
\hline
\end{tabular}

Using measured electrical data. water flow rate can be evaluated using formula (6) to (10) it appears that for the whole month, the water volume produced by the station of Agola and Dorigué are respectively $210.234 \mathrm{~m}^{3}$ and $157.676 \mathrm{~m}^{3}$ while 
mean daily water volume are respectively $6.782 \mathrm{~m}^{3}$ and $5.086 \mathrm{~m}^{3}$.These quantities can be use to design for a specific station in the same climatic locations water requirements for a population of a given size depending on the nature of the users (humans, animals) or the use. The daily flow rate are presented in the Table 6.

Table 6. Daily flow rate of the stations of Agola and Dorigué.

\begin{tabular}{llllll}
\hline days & \multicolumn{2}{l}{ daily water volume $\left(\mathbf{m}^{3}\right)$} & days & \multicolumn{2}{l}{ daily water volume $\left(\mathbf{m}^{3}\right)$} \\
\hline 1 & Agola & Dorigué & & Agola & Dorigué \\
2 & 8.226 & 6.169 & 16 & 6.322 & 4.742 \\
3 & 8.014 & 6.011 & 17 & 5.871 & 4.403 \\
4 & 8.057 & 6.043 & 18 & 5.517 & 4.138 \\
5 & 5.517 & 4.138 & 19 & 6.854 & 5.140 \\
6 & 6.609 & 4.957 & 20 & 6.133 & 4.600 \\
7 & 5.734 & 4.300 & 21 & 6.618 & 4.963 \\
8 & 6.159 & 4.619 & 22 & 5.577 & 4.183 \\
9 & 7.216 & 5.412 & 23 & 6.942 & 5.206 \\
10 & 9.251 & 6.938 & 24 & 8.290 & 6.217 \\
11 & 6.383 & 4.788 & 25 & 5.517 & 4.138 \\
12 & 8.618 & 6.463 & 26 & 6.609 & 4.957 \\
13 & 6.609 & 4.957 & 27 & 6.444 & 4.833 \\
14 & 8.591 & 6.443 & 28 & 8.379 & 6.284 \\
15 & 5.207 & 3.905 & 29 & 6.426 & 4.820 \\
& 6.068 & 4.551 & 30 & 5.623 & 4.217 \\
Monthly Total $\left(\mathrm{m}^{3}\right)$ & & & 31 & 6.854 & 5.140 \\
daily mean $\left(\mathrm{m}^{3}\right)$ & & 210.234 & & 157.676 & 5,086 \\
\hline
\end{tabular}

For the two special days water flow rate profile are shown in Figure 9 and 10. It appears that for the same climatic conditions flow rate depend on TDH. For the station of Agola flow rate vary from 0 to $1.237 \mathrm{~m}^{3} / \mathrm{h}$ while in Dorigué it vary from 0 to $0.928 \mathrm{~m}^{3} / \mathrm{h}$ for the worst day corresponding to the $4^{\text {th }}$ of August. For the sunny day, $\left(09^{\text {th }}\right.$ of August $)$, in Agola flow rate vary from 0 to $1.919 \mathrm{~m}^{3} / \mathrm{h}$ while in Dorigué it vary from 0 to $1.439 \mathrm{~m}^{3} / \mathrm{h}$.

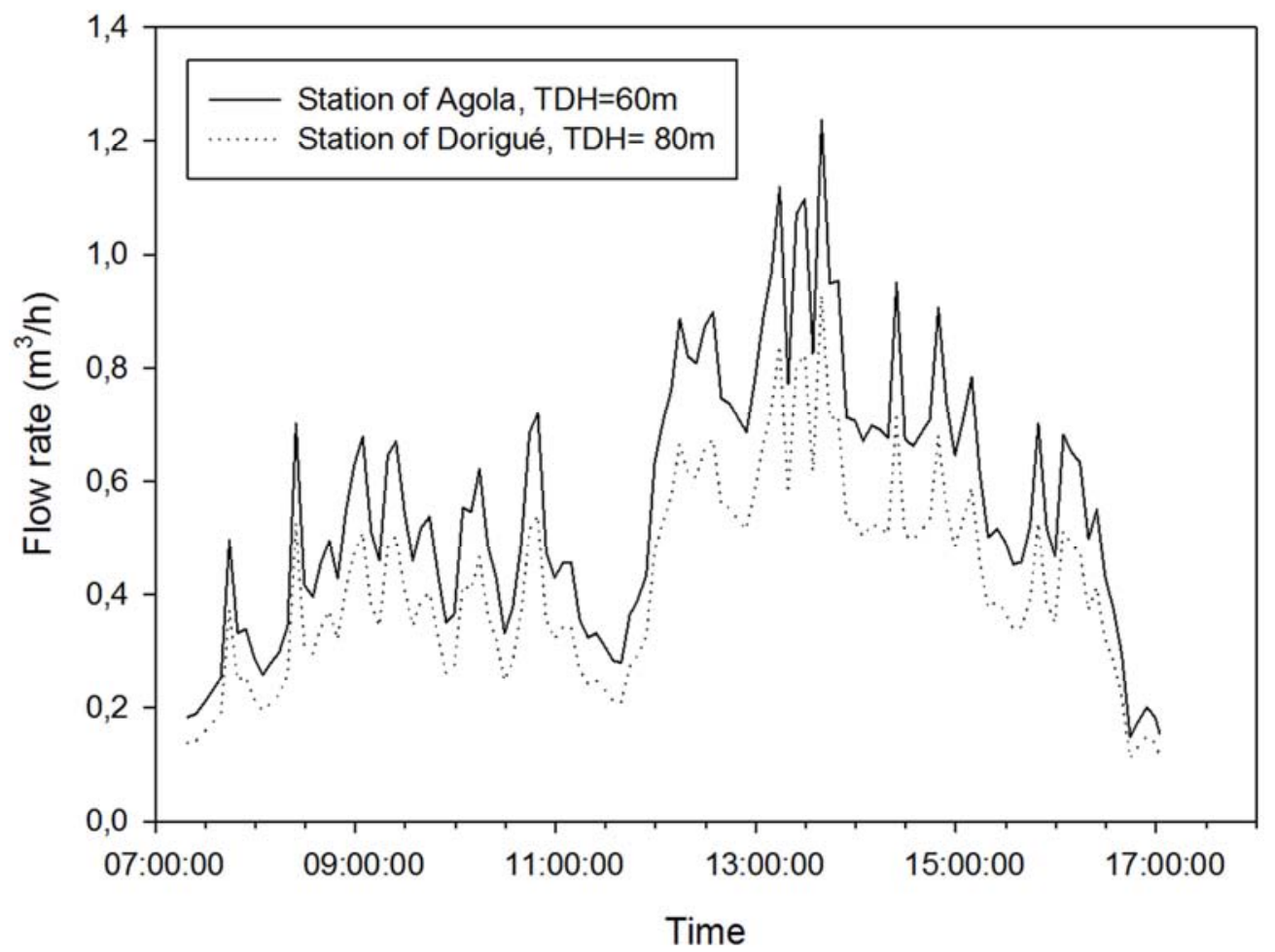

Figure 9. Flow rate on 04th of August in the Stations of Agola and Dorigué. 


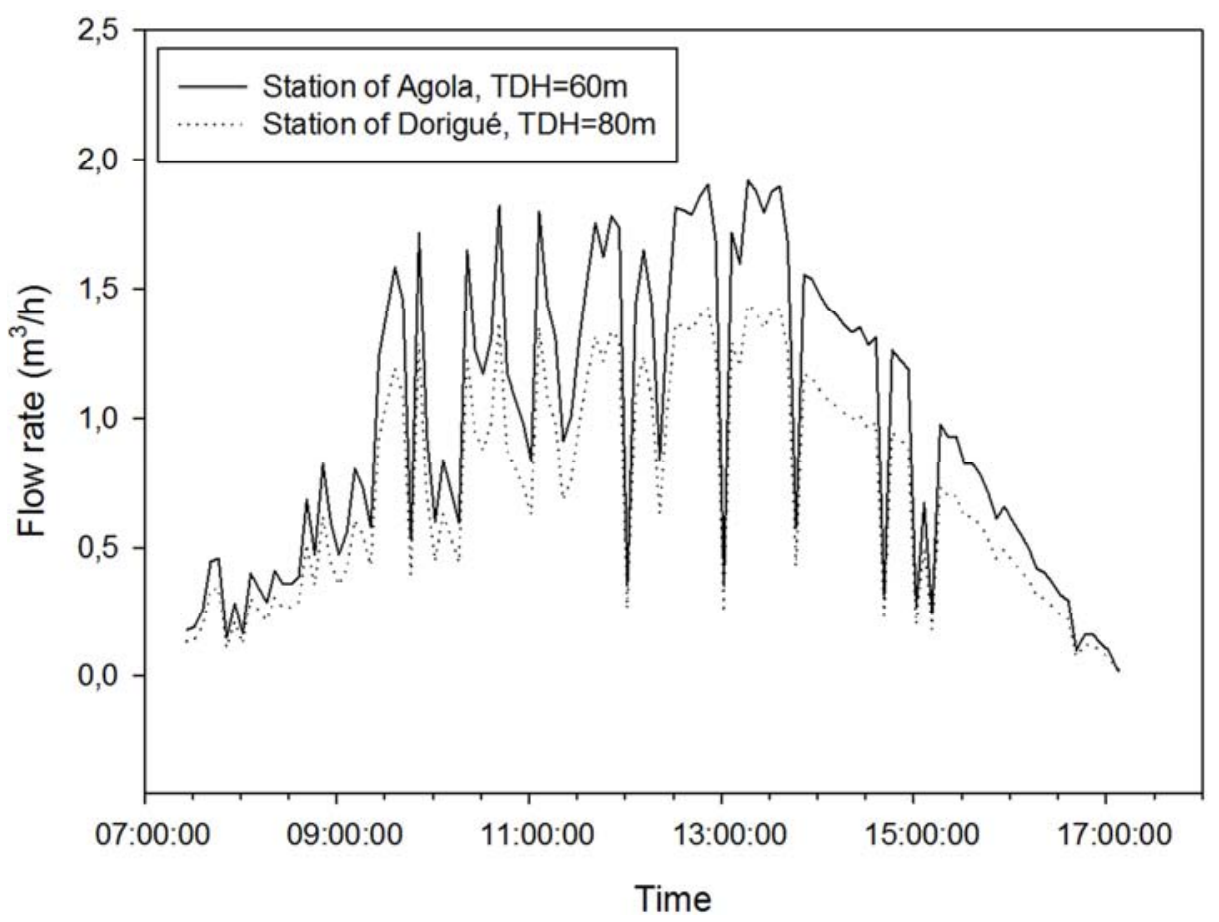

Figure 10. Flow rate on 09th of August in the Stations of Agola and Dorigué.

\section{Conclusion}

The performance of a PV module at a specific climate has been analyzed. A model for water pumping system was developed and implemented with experimental data measured in two stations in the far north region of Cameroon for the month of august considered as the rainy month in the soudano-sahelian climate of Cameroon. It was found that for this month the cloudy day correspond to $04^{\text {th }}$ of august while the sunny day correspond to the $9^{\text {th }}$ of august. for the two experimental stations of Agola and Dorigué the water volume produced by the station were respectively $210.234 \mathrm{~m}^{3}$ and $157.676 \mathrm{~m}^{3}$ while mean daily water volume were respectively $6.782 \mathrm{~m}^{3}$ and $5.086 \mathrm{~m}^{3}$. These quantities could be used to design water requirements for a specific station in the same climatic locations for a population of a given size depending on the nature of the users (humans, animals).

\section{Nomenclature}

$\begin{array}{ll}A & \text { area of the array }\left(\mathrm{m}^{2}\right) \\ D & \text { Inside diameter of the pipe }(\mathrm{m}) \\ E_{h y d r} & \text { hourly hydraulic energy demand }(\mathrm{Wh}) \\ f & \text { friction factor } \\ F F & \text { filling factor } \\ g & \text { acceleration of gravity }\left(9.81 \mathrm{~m} / \mathrm{s}^{2}\right) \\ H_{f} & \text { Head losses }(\mathrm{m}) \\ I_{s c} & \text { short circuit current }(\mathrm{A}) \\ I_{m} & \text { maximum current }(\mathrm{A}) \\ h & \text { lifting water height }(\mathrm{m}) \\ P_{m} & \text { maximum power }(\mathrm{W}) \\ Q & \text { hourly water volume }\left(\mathrm{m}^{3} \mathrm{~h}\right) \\ R_{\mathrm{p}} & \text { pump system efficiency }(\%)\end{array}$

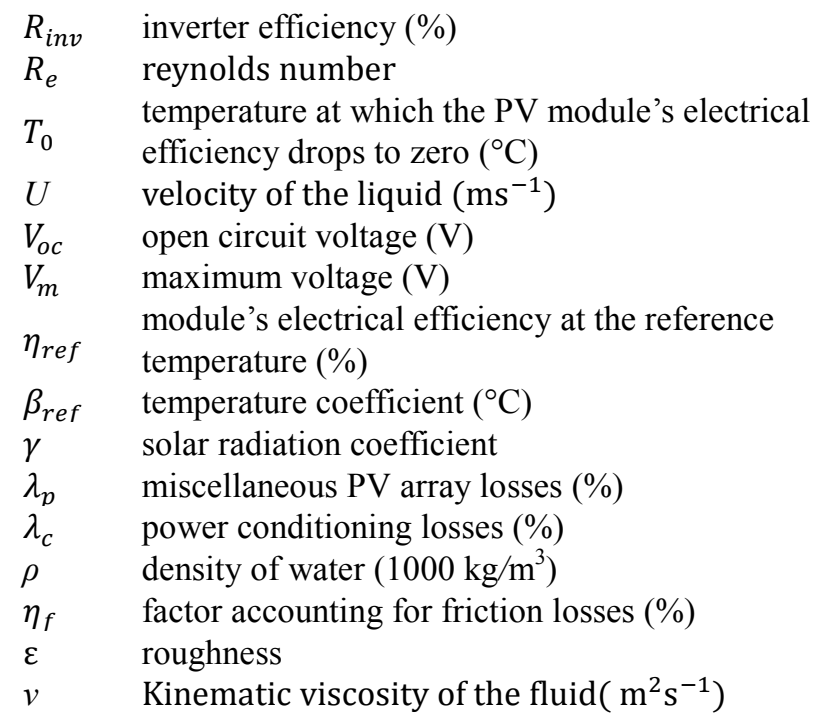

\section{References}

[1] Khatib, T., A Ibrahim, M. Azah. 2016 “A review on sizing methodologies of photovoltaic array and storage battery in a standalone photovoltaic system." Energy Conversion and Management 120:430-448.

[2] Mahjoubi, A., R. F. Mechlouch, B. Mahdhaoui and A. Ben Brahim. 2013 "Realtime performance models for photovoltaic water pumping systems." International Journal of Ambient Energy, DOI: 10.1080/01430750.2013.853203.

[3] Diaf, S., G. Notton, M. Belhamel, M. Haddadi, A. Louche. 2008 "Design and technoeconomical optimization for hybrid $\mathrm{PV} /$ wind system under various meteorological conditions." Appl Energy; 85:968-987. 
[4] Kaldellis, J. K., K. Kavadias, D. Zafirakis. 2012 "Experimental validation of the optimum photovoltaic panels' tilt angle for remote consumers." Renew Energy 46:179-191.

[5] Marion, B., 2002, "A Method for Modeling the CurrentVoltage Curve of a PV Module for Outdoor Conditions," Prog. Photovoltaics 10, pp. 205-214.

[6] Kroposki, B., W. Marion, D. L. King, W. E. Boyson, and J. Kratochvil. 2002, "Comparison of Module Performance Characterization Methods for Energy Production," Paper No. NREL/TP-520-29245.

[7] Fanney, A. H., M. W. Davis, B. P. Dougherty, D. L. King, W. E. Boyson, J. A. Kratochvil. 2006, "Comparison of photovoltaic module performance measurements." J. Sol. Energy Eng. 128: 152-159, http://dx.doi.org/10.1115/ 1.2192559

[8] Tao Ma, Hongxing Yang, Lin Lu. 2014 "Solar photovoltaic system modeling and performance prediction." Renewable and Sustainable Energy Reviews 36: 304-315.

[9] Picault, D., B. Raison, S. Bacha, J. de la Casa, J. Aguilera. 2010 "Forecasting photovoltaic array power production subject to mismatch losses." Solar Energy 84:1301-1309.

[10] Carr, A. J. and T. L. Pryor. 2004 A comparison of the performance of different PV module types in temperate climates. Solar Energy 76: 285-294.

[11] Amin N., Chin Wen Lung and S. Kamaruzzaman. A practical field study of various solar cells on their performance in Malaysia. Renewable Energy 34 (2009) 1939-1946.

[12] Anser M. B., M. A. Hafiz, S. Khalil, A. Muzaffar and M. S. Aysha. 2014 Comparison of Performance Measurements of Photovoltaic Modules during Winter Months in Taxila, Pakistan. International Journal of Photoenergy. Article ID 898414, 8 pages http://dx.doi.org/10.1155/2014/898414.

[13] Aoun, N., B. Kada, R. Chenni. 2017 Performance Evaluation of a Mono-Crystalline Photovoltaic Module Under Different Weather and Sky Conditions. INTERNATIONAL JOURNAL of RENEWABLE ENERGY RESEARCH. 7 (1): 292-297.

[14] Ataei, A., M. Biglari, M. Nedaei, E. Assareh, Jun-Ki Choi, ChangKyoo Yoo and M. S. Adaramola. 2015 TechnoEconomic Feasibility Study of Autonomous Hybrid Wind and Solar Power Systems for Rural Areas in Iran, A Case Study in Moheydar Village. Environmental Progress \& Sustainable Energy 34 (5): 1521-1527.

[15] Bianchini A., M. Gambuti, M. Pellegrini, C. Saccani. 2016 "Performance analysis and economic assessment of different photovoltaic technologies based on experimental measurements." Renewable Energy 85: 1-11.

[16] Khatib, T., A. Mohamed, K. A. Sopian. 2013 "review of photovoltaic systems size optimization techniques." Renew Sustain Energy Rev 22:454-65. http://dx.doi.org/10.1016/j.rser.2013.02.023.

[17] Chandel, S. S., M. Nagaraju Naik, Rahul Chandel. 2015 Review of solar photovoltaic water pumping system technology for irrigation and community drinking water supplies. Renewable and Sustainable Energy Reviews 49: 1084-1099.

[18] Hosseini, S. H., S. F. Ghaderi, G. H. Shakouri. 2012 “An investigation on the main influencing dynamics in renewable energy development: a systems approach" p. 92-7. http://dx.doi.org/10.1109/ICREDG.2012.6190476.

[19] Sontake V. C. and V. R. Kalamkar. 2016 Solar photovoltaic water pumping system - A comprehensive review. Renewable and Sustainable Energy Reviews 59 (2016) 1038-1067.

[20] Mahjoubi, A., R. F. Mechlouch, A. Ben Brahim. 2012 "Prediction of Hourly Flow Rate of a Photovoltaic Water Pumping System in the Desert of Tunisia." International Journal of Green Energy 9 (3): 202-217, DOI: 10.1080/15435075.2011.621476.

[21] A. Al-Badi, H. Yousef, T. Al Mahmoudi, M. Al-Shammaki, A. Al-Abri \& A. AlHinai (2017): Sizing and modelling of photovoltaic water pumping system, International Journal of Sustainable Energy, DOI: 10.1080/14786451.2016.1276906.

[22] Grunfos, "SQflex Renewable-energy based water-supply systems 50/60 Hz." Bjerringbro, Grundfos Data Booklet.

[23] Notton, G., C. Cristofari, M. Mattei and P. Poggi. 2005 "Modelling of a double-glass photovoltaic module using finite differences." Appl. Therm. Eng., 25:2854-2877.

[24] Evans, D. L. 1981. "Simplified method for predicting photovoltaic array output." Solar Energy 27 (6): 555-560.

[25] Evans, D. L. and L. W. Florschuetz. 1977 "Cost studies on terrestrial photovoltaic power systems with sunlight concentration" Sol. Energ., 19:255-262.

[26] Hart, G. W. and P. Raghuraman. 1982 MIT Report, DOE/ET/20279-202.

[27] Garg, H. P. and R. K. Agarwal. "Some aspects of a PV/T collector/forced circulation flat plate solar water heater with solar cells" Energ. Convers. Manag., 36: 87-99.

[28] Evans D L, L. W. Florschuetz. 1978 "Terrestrial concentrating photovoltaic power system studies.” Sol Energy 20:37-43.

[29] Royer, J., T. Djiako, E. Schiller, and B. S. Sy. 1998. Photovoltaic pumping: Handbook of course for the engineers and technicians, Institute of the Energy of the Countries having jointly the use of the French, Quebec, Canada.

[30] Crane, 1982. "flows of fluids through valves, Fittings and Pipe, Metric edition." New York, Technical paper N $410 \mathrm{M}$.

[31] Burt, J., and P. E. Rishel. 2002 "water pumps and pumping systems." New York, McGraw-Hill.

[32] Ebaid, S. Y., H. Qandil, M. Hammad. 2013 "A unified approach for designing a photovoltaic solar system for the underground water pumping well-34 at Disi aquifer." Energy Conversion and Management 75:780-795.

[33] Grundfos. "The centrifugal pump GRUNDFOS Management". 